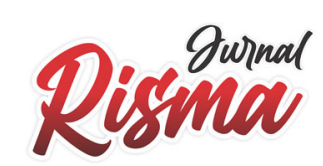

Vol. 1 No. 3 September 2021

\title{
PENGARUH SISTEM INFORMASI AKUNTANSI MANAJEMEN,BUDGET DAN KETIDAKPASTIAN LINGKUNGAN TERHADAP KINERJA MANAJERIAL KOPERASI SYARIAH DI PULAU LOMBOK
}

\author{
Ria Mawaddah \\ riamawaddah671@gmail.com \\ Jurusan Akuntansi Fakultas Ekonomi dan Bisnis Universitas Mataram \\ Animah \\ animahmtr@unram.ac.id \\ Jurusan Akuntansi Fakultas Ekonomi dan Bisnis Universitas Mataram \\ Lalu Takdir Jumaidi \\ takdir.jumaidi@unram.ac.id \\ Jurusan Akuntansi Fakultas Ekonomi dan Bisnis Universitas Mataram
}

\begin{abstract}
ABSTRAK
Penelitian ini bertujuan untuk menguji pengaruh sistem informasi akuntansimanajemen, budget dan ketidakpastian lingkungan terhadap kinerja manajerial. Pengujian dilakukan pada 40 (empat puluh) manajer koperasi syariah di Pulau Lombok yang terdiri dari 5 Kabupaten atau kota, yaitu Kota Mataram, Kabupaten Lombok Barat, Kabupaten Lombok Tengah, Kabupaten Lombok Timur, dan kabupaten Lombok Utara. Teknik pengolahan data dalam penelitian ini dilakukan dengan menggunakan metode SEM berbasis varian (SEM PLS) dengan menggunakan aplikasi software SmartPLS 3.0. Hasil penelitian ini menunjukkan bahwa budget dan ketidakpastian lingkungan berpengaruh signifikan terhadapkinerja manajerial, sedangkan sistem informasi akuntansi manajemen berpengaruhnamun tidak signifikan terhadap kinerja manajerial. Hasil dari temuan penelitian inimempunyai implikasi bagi koperasi syariah, baik manajer koperasi syariah, pengawas maupun anggota koperasi syariah secara umum khususnya di Pulau Lombok dalam mengambil keputusan dalam merumuskan kebijakan terkait penerapan sistem informasi akuntansi manajemen, budget dan mampu mengantisipasi ketidakpastian lingkungan serta dapat membuat keputusan-keputusan yang tepat untuk meningkatkan kinerja manajerial.
\end{abstract}

Kata kunci: sistem informasi akuntansi manajemen, budget, ketidakpastianlingkungan, kinerja manajerial

\section{PENDAHULUAN}

\section{Latar Belakang}

Lembaga keuangan syariah menjadi lembaga keuangan paling diminati di Indonesia terutama oleh masyarakat Muslim. Kemajuan tersebut menunjukkan bahwa perkembangan ekonomi dengan sistem Islam mendapatkan tempat tersendiri di hati masyarakat. Lembaga keuangan syariah terdiri dari Bank Umum Syariah (BUS), Bank Pembiayaan Rakyat Syariah (BPRS), dan juga telah lahir lembaga keuangan baru yaitu koperasi syariah yang pada dasarnya merupakan lembaga keuangan non-bank atau lembaga keuangan mikro syariah (Lasmiatun, 2010).

Koperasi syariah memiliki beberapa jenis yaitu Koperasi Jasa Keuangan Syariah (KJKS), Koperasi Simpan Pinjam Pembiayaan Syariah (KSPPS) dan UnitSimpan Pinjam Pembiayaan Syariah (USPPS) atau biasa dikenal dengan baitul maal wa tamwil. Data dari Pusat Inkubasi Bisnis Usaha Kecil (PINBUK), jumlah koperasi syariah dari tahun ke tahun mengalami peningkatan. Pada tahun 2019 jumlah koperasi syariah di Indonesia diperkirakan mencapai 4.500-5.500 koperasi syariah. Lombok sebagai pulau dengan mayoritas Muslim juga memiliki ratusan koperasi syariah yang tersebar di 5 (lima) 
Kabupaten/ Kota. Total koperasi syariahdi Pulau Lombok tahun 2014-2019 mencapai 301 koperasi syariah, dengan 246 koperasi syariah binaan kabupaten dan 55 koperasi syariah binaan provinsi. (DinasKoperasi dan UMKM Provinsi NTB, 2019)

Keberadaan koperasi syariah dengan jumlah yang signifikan pada beberapadaerah di Indonesia masih belum memiliki faktor-faktor pendukung yang memungkinkan koperasi syariah untuk terus berkembang dan berjalan dengan baik. Banyak koperasi syariah yang terancam bubar disebabkan manajemen yang kurangprofesional, pengelola yang tidak amanah, sumber daya manusia yang kurang bekerja secara efektif dan efisien, kurangnya kepercayaan masyarakat, kesulitan modal dan sebagainya (Wulan, 2014). Seperti yang terjadi pada 324 koperasi syariah yang ada di Jawa Tengah pada 2017 yang terancam tutup karena manajemenperusahaan yang kurang baik (kontan.co.id). Meskipun koperasi syariah merupakanlembaga keuangan mikro, dalam melakukan kegiatannya juga harus didukung olehkinerja manajerial yang baik untuk keberlangsungan dan perkembangan koperasi syariah tersebut.

Kinerja sebagai acuan yang berkaitan erat dengan kegiatan melakukan pekerjaan, dalam hal ini meliputi hasil kerja yang dicapai. Secara umum dapat dikatakan bahwa kinerja merupakan prestasi yang dapat dicapai oleh individu organisasi dalam periode tertentu. Kebutuhan berprestasi (sence of achievement) tersebut merupakan salah satu kebutuhan terkuat dalam diri manusia. Dalam kebutuhan ini manusia merasa hal yang menjadi pekerjaan penting sehingga akan menyelesaikan pekerjaan itu dengan lebih baik. Kinerja manajerial dalam kegiatan manajerial meliputi perencanaan, investigasi, koordinasi, evaluasi, pengawasan, pengaturan staf, negosiasi dan perwakilan (Narsa, 2007). Oleh karena itu meskipunkoperasi syariah merupakan lembaga keuangan mikro, dalam melakukan kegiatannya juga harus didukung oleh kinerja manajerial yang baik demi keberlangsungan dan perkembangan koperasi syariah (Rahmi, 2019).

Informasi akuntansi manajemen diperlukan oleh berbagai tingkat manajemen, baik manajemen atas, manajemen menengah, maupun manajemen bawah. Pada dasarnya informasi yang dibutuhkan oleh setiap tingkat manajemen berbeda satu dengan yang lainnya. Budget menjadi satu bagian penting dalam proses perencanaan dan keberlanjutan usaha koperasi syariah. Adanya pencatatan anggaran, suatu organisasi juga dapat memperhitungkan perencanaan untuk langkah-langkah yang akan dilaksanakan berdasarkan jenjang waktu baik itu jangkapendek, jangka menengah serta jangka panjang. Penyusunan anggaran dalam koperasi syariah biasanya dilakukan 1 (satu) kali dalam 1 (satu) tahun dalam RapatAnggota Tahunan (RAT). Rapat anggota tahunan membahas penyusunan rencana anggaran pendapatan dan belanja koperasi dilaksanakan sebelum akhir tahun bukuatau sebelum memasuki tahun berikutnya (Aulia, 2018).

Ketidakpastian lingkungan adalah variabel lain yang dipertimbangkan dalam penelitian ini. Ketidakpastian lingkungan yang tinggi terjadi ketika rasa ketidakmampuan individu untuk memprediksi sesuatu yang terjadi di lingkungan secara akurat. Ketidakpastian lingkungan merupakan salah satu faktor yang sering menyebabkan organisasi melakukan penyesuaian terhadap kondisi organisasi dengan lingkungan. Seseorang mengalami ketidakpastian karena merasa tidakmemiliki informasi yang cukup untuk memprediksi keadaan pada masa yang akandatang (Bashirudin, 2015). Selain itu, menurut Merchant dan Stede (2014) ketidakpastian akan lebih tinggi saat laju perubahan teknologi yang tinggi, ketika mencoba untuk melihat masa depan, ketika siklus bisnis yang terlalu panjang.

Pada penelitian sebelumnya yang dilakukan oleh Bashirudin (2015) mengenai "Pengaruh Sistem Informasi Akuntansi Manajemen, Human Capital danKetidakpastian 


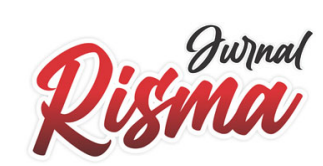

Vol. 1 No. 3 September 2021

Lingkungan terhadap Kinerja Manajerial pada Baitul Maal wat Tamwil di Wilayah DKI Jakarta", dikemukakan bahwa sistem informasi akuntansimanajemen berpengaruh secara signifikan terhadap kinerja manajerial. Hal tersebut didukung oleh penelitian yang dilakukan oleh Herawati (2015), Angelina (2018), Irawati (2018), Prihatningtyas (2018), Suryani (2019), Dahlan (2019) dan Rahmi (2019) yang menyatakan bahwa sistem informasi akuntansi manajemen berpengaruh terhadap kinerja manajerial.

Menurut Karakoc (2016) dalam penelitiannya mengenai pengaruh budget dan job performance menyatakan bahwa partisipasi anggaran memiliki pengaruh yang signifikan secara statistik dan terhadap kinerja entitas. Hasil penelitian tersebut juga didukung oleh penelitian yang dilakukan oleh Suparmun (2015), Popesko (2017) dan Dahlan (2019) yang menyatakan bahwa partisipasi anggaran memiliki pengaruh yang signifikan.

Berkaitan dengan ketidakpastian lingkungan, Rahmi (2019) melakukan penelitian pada PT Bosnawa Berlian Motor Makassar. Dari hasil penelitiannya disimpulkan bahwa ketidakpastian lingkungan berpengaruh terhadap kinerja manajerial. Ketidakpastian lingkungan yang tinggi diidentifikasi sebagai faktor yang penting karena kondisi demikian dapat menyulitkan perencanaan dan pengendalian. Penelitian tersebut juga didukung oleh Herawati (2015), Eriani(2019), Kesumawati (2019) dan Prihatningtyas (2018) yang menyatakan bahwa Ketidakpastian lingkungan berpengaruh positif dan signifikan terhadap kinerja manajerial, walaupun pada penelitian Bashirudin (2015) menyatakan bahwa ketidakpastian lingkungan tidak berpengaruh terhadap kinerja manajerial.

Berdasarkan pada penelitian terdahulu dan fenomena-fenomena yang telah diuraikan di atas. Peneliti tertarik untuk melakukan penelitian mengenai pengaruh sistem informasi akuntansi manajemen, budget dan ketidakpastian lingkunganterhadap kinerja manajerial koperasi syariah di Pulau Lombok.

\section{Rumusan Masalah}

Mengacu pada latar belakang penelitian yang telah disampaikan, maka rumusan masalah penelitian ini adalah sebagai berikut:

1. Apakah sistem informasi akuntansi manajemen dapat mempengaruhi kinerja manajerial?

2. Apakah budget dapat mempengaruhi kinerja manajerial?

3. Apakah ketidakpastian lingkungan dapat mempengaruhi kinerjamanajerial?

\section{KAJIAN PUSTAKA DAN PENGEMBANGAN HIPOTESIS Teori Perilaku Terencana (Planned Behavior Theory)}

Teori perilaku terencana pada dasarnya merupakan teori pengembangan dari teori sebelumnya yakni theory of reasoned action yang dikembangkan oleh Icek Ajzen dan Martin Fisben (1985). Teori ini menjelaskan bahwa sebuah perilakuterbentuk karena adanya niat untuk berperilaku. Niat ini diartikan sebagai respon atau kesiapan seseorang untuk menunjukkan tindakan atau perilaku. Selain itu, dalam teori ini dijelaskan bahwa seseorang sebelum berperilaku menggunakan informasi yang sistematik untuk memahami dampak yang akan timbul dari perilakunya tersebut (Kreshastuti, 2014).

\section{Teori Kontijensi}

Teori kontinjensi menyatakan semua komponen dari suatu organisasi harus terdapat kecocokan atau kesesuaian antara satu dengan yang lain. Teori kontinjensiuntuk menganalisis dan merancang sistem pengendali, khususnya di bidang informasi akuntansi manajemen (Otley, 1980 dalam Wirjono, 2013). Implikasi teori terencana terhadap penelitian ini, yaitu dapat menjelaskan tingkat keandalan sistem informasi akuntansi 
manajemen dalam berbagai kondisi. Beberapa variabel kontijensi yang digunakan dalam penelitian tentang sistem akuntansi manajemen antara lain ketidakpastian lingkungan, ketidakpastian tugas dan sebagainya. Dalampenelitian ini, pendekatan teori kontijensi yang akan diadopsi untuk mengevaluasi keefektifan informasi sistem akuntansi manajemen terhadap kinerja manajerial adalah ketidakpastian lingkungan dan budget.

\section{Teori Goal-Setting}

Teori penetapan tujuan atau goal setting theory awalnya dikemukakan olehLocke (1968), yang menunjukkan adanya keterkaitan antara tujuan dan kinerja seseorang terhadap tugas. Teori ini menjelaskan bahwa perilaku seseorang ditentukan oleh dua cognition yaitu content (values) dan intentions (tujuan). Orangtelah menentukan goal (tujuan/ sasaran) atas perilakunya di masa depan dan goal tersebut akan mempengaruhi perilaku yang sesungguhnya terjadi. Implikasi teori goal-setting terhadap penelitian ini, yaitu dapat menjelaskan penentuan sasaran (goal) yang spesifik seorang manajer dalam perannya untuk berpartisipasi dalam perumusan anggaran. Seseorang akan mampu membandingkan apa yang telah dilakukan dengan sasaran (goal) yang spesifik sehingga tujuan entitas dapat dicapai.

\section{Teori Atribusi (Attribution Theory)}

Teori atribusi dalam penelitian ini digunakan untuk menjelaskan tentang perilaku penyelenggara anggaran. Teori atribusi (Attribution Theory) pertama kalidiperkenalkan oleh Fritz Heider (1958). Teori atribusi ini merupakan sebuah teori yang menjelaskan tentang perilaku seseorang dan mempelajari proses bagaimana seseorang mengintepretasikan atau menafsirkan terjadinya suatu peristiwa, alasan atau sebab perilakunya. Heider berargumen bahwa perilaku seseorang ditentukan oleh kombinasi antara kekuatan internal (internal forces) yaitu faktor-faktor yang berasal dari dalam diri seseorang misalnya kemampuan, pengetahuan atau usaha, motivasi dan kekuatan eksternal (external forces) yaitu faktor-faktor yang berasal dari luar seperti prestasi atau kinerja, kesulitan dalam pekerjaan atau keberuntungandalam pekerjaan. Teori atribusi dalam konteks ini banyak digunakan peneliti untuk menjelaskan mengenai penilaian kinerja organisasi oleh penyelenggara anggaran. Atribusi berhubungan dengan penilaian dan menjelaskan bagaimana seorang.

\section{Sistem Informasi Akuntansi Manajemen}

Sistem informasi akuntansi manajemen merupakan salah satu faktor yang mempengaruhi kinerja manajer. Sistem informasi akuntansi manajemen menyediakan informasi yang tepat bagi manajer. Dari hasil penelitian Chenhall danMorris (1986:10) seperti yang dikutip ditemukan bukti empiris mengenai karakteristik informasi akuntansi manajemen yang bermanfaat berdasarkan persepsi para manajerial sebagai pengambil keputusan dikategorikan kedalam empat sifat yaitu Broadscope (informasi yang memperhatikan dimensi fokus, timehorizon dan kualifikasi), Agregastion (Informasi disampaikan dalam bentuk yang lebih ringkas tetapi tetap mencangkup hal-hal penting), Integration (Informasi yangterintegrasi) dan Timeliness (tepat waktu)

\section{Budget}

Anggaran atau budget merupakan suatu rencana yang disusun secara sistematis dalam bentuk angka dan dinyatakan dalam unit moneter yang meliputi seluruh kegiatan perusahaan untuk jangka waktu (periode) tertentu di masa yang akan datang. Penganggaran partisipatif merupakan proses yang menggambarkan setiap individu akan terlibat dalam proses penyusunan anggaran dan mempunyai pengaruh terhadap target anggaran, serta adanya penghargaan atas pencapaian anggaran tersebut. Brownell dalam Falikatun (2007, hal 23) menyatakan bahwa indikator partisipasi anggaran yaitu; 


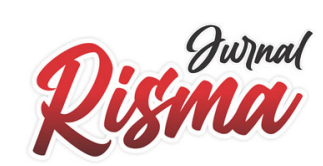

Vol. 1 No. 3 September 2021

keterlibatan, pengaruh dan komitmen.

\section{Ketidakpastian Lingkungan}

Ketidakpastian lingkungan yang dimaksud adalah persepsi responden atas ketidakmampuan individu untuk menilai probabilitas dirinya sebesar keputusan yang telah dibuat, akan gagal atau berhasil yang disebabkan karena kesulitan untuk memprediksi kemungkinan-kemungkinan yang akan terjadi. Ketidakpastian lingkungan yang tinggi akan menyebabkan manajer sulit menyusun perencanaan dan pengendalian organisasi yang tepat.

\section{Kinerja Manajerial}

Kinerja (performance) adalah hasil yang dapat dicapai oleh seseorang atau sekelompok orang dalam suatu organisasi, sesuai dengan wewenang dan tanggungjawab masing-masing, dalam rangka mencapai tujuan organisasi. Seseorang yang memegang posisi manajerial diharapkan mampu menghasilkan suatu kinerja manajerial. Berbeda dengan kinerja karyawan yang umumnya bersifat konkrit, kinerja manajerial adalah bersifat abstrak dan kompleks (Mulyadi dan Johny, 2001:80).

Narsa (2007) menyatakan kinerja manajerial adalah kinerja para individu dalam kegiatan manajerial. Kinerja personel meliputi delapan dimensi yaitu:

1. Perencanaan; dalam arti kemampuan untuk menentukan tujuan, kebijakan dan tindakan/pelaksanaan, penjadwalan kerja, penganggaran, merancang prosedur, dan pemrograman.

2. Investigasi; yaitu kemampuan mengumpulkan dan menyampaikan informasi untuk catatan, laporan, dan rekening, mengukur hasil, menentukan persediaan, dan analisis pekerjaan.

3. Pengkoordinasian; yaitu kemampuan melakukan tukar menukar informasi dengan orang lain di bagian organisasi yang lain untuk mengaitkan dan menyesuaikan program, memberitahukan bagian lain, dan hubungan dengan manajer lain.

4. Evaluasi; yaitu kemampuan untuk menilai dan mengukur proposal, kinerjayang diamati atau dilaporkan, penilaian pegawai, penilaian catatan hasil, penilaian laporan keuangan, pemeriksaan produk.

5. Pengawasan (supervisi), yaitu kemampuan untuk mengarahkan, memimpin dan mengembangkan bawahan, membimbing, melatih dan menjelaskan peraturan kerja pada bawahan, memberikan tugas pekerjaan dan menanganibawahan.

6. Pengaturan staff (staffing); yaitu kemampuan untuk mempertahankan angkatan kerja, merekrut, mewawancarai dan memilih pegawai baru, menempatkan, mempromosikan dan mutasi pegawai.

7. Negosiasi; yaitu kemampuan dalam melakukan pembelian, penjualan atau melakukan kontrak untuk barang dan jas-, menghubungi pemasok, tawar menawar dengan wakil penjual, tawar-menawar se ara kelompok.

8. Perwakilan (representatif); yaitu kemampuan dalam menghadiri pertemuanpertemuan dengan perusahaan lain, rapat, diskusi, pertemuan perkumpulan bisnis, pidato untuk acara-acara kemasyarakatan dan sosial, pendekatan kemasyarakatan, mempromosikan tujuan umum perusahaan. 


\section{Rerangka Konseptual}

Pengaruh Sistem Informasi Akuntansi Manajemen, Budget Dan Ketidakpastian Lingkungan terhadap Kinerja Manajerial Koperasi Syariah di Pulau Lombok

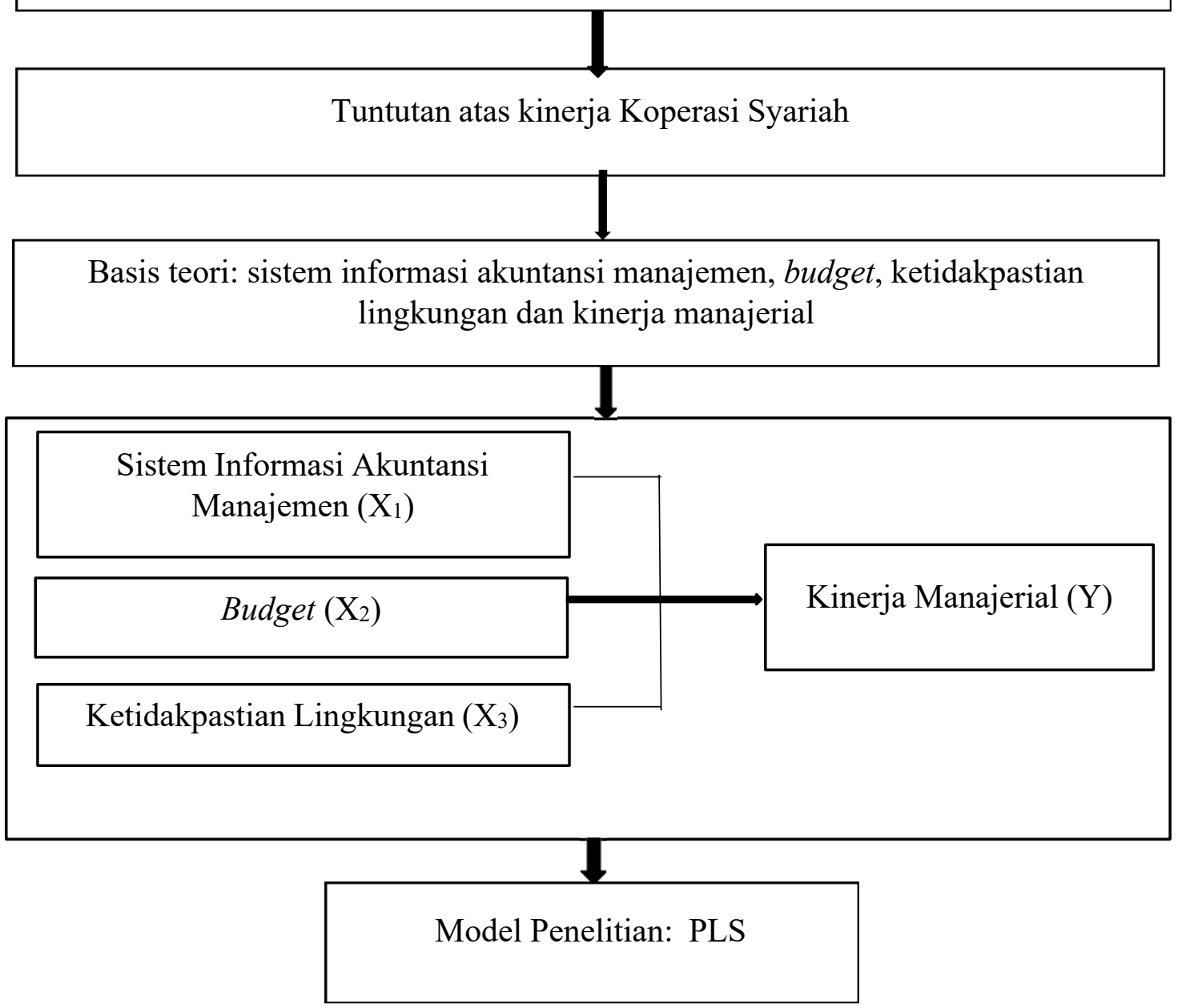

Hasil Pengujian dan Pembahasan

Kesimpulan, Implikasi dan Saran

Gambar 2.1 Skema Rerangka Pemikiran

\section{Pengembangan Hipotesis}

Pengaruh Sistem Informasi Akuntansi Manajemen Terhadap KinerjaManajerial

Teori Planned behavior theory menjelaskan bahwa sikap seorang manajer dalam menggunakan sistem informasi untuk meningkatkan kinerja manajerial yangtidak terlepas 


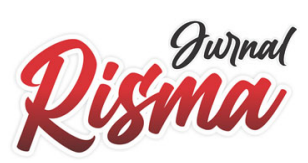

Vol. 1 No. 3 September 2021

pada attitude toward behavior, subjective norm dan perceived behavior control. Planned behavior theory yang mempengaruhi sikapnya dalam pengambilan keputusan sesuai dengan keadaan dan kebutuhan entitasnya

Beberapa penelitian mengenai informasi sistem akuntansi manajemen yang dihubungkan dengan variabel kontekstual dan kinerja manajerial telah banyak dilakukan. Penelitian yang melibatkan keempat karakteristik informasi sistem akuntansi manajemen diantaranya dilakukan oleh Chenhall dan Morris (1986), Chia(1995), Miah and Mia (1996), Nazarudin (1998). Penelitian terbaru juga berhasil membuktikan bahwa sistem informasi akuntansi manajemen berpengaruh terhadapkinerja manajerial seperti pada penelitian yang dilakukan oleh Bashirudin (2015), Herawati (2015), Angelina (2018), Irawati (2018), Prihatningtyas (2018), Suryani (2019), Dahlan (2019) dan Rahmi (2019). Walaupun ini bertentangan dengan penelitian Yunifa Fujiastuti (2008) yang menunjukkan bahwa sistem informasi akuntansi manajemen tidak berpengaruh signifikan terhadap kinerja manajerial.

Berdasarkan uraian di atas, peneliti merasa perlu melakukan pengujian kembali mengenai pengaruh sistem informasi akuntansi manajemen terhadap kinerja manajerial untuk memperkuat pendapat-pendapat dari penelitian sebelumnya. Sehingga rumusan hipotesis yang diajukan adalah:

$\mathrm{H}_{1}$ : Sistem informasi akuntansi manajemen berpengaruh terhadap kinerja manajerial Pengaruh budget terhadap kinerja manajerial

Seperti yang disampaikan oleh Hansen \& Mowen (2010), bahwa sebuah sistem penganggaran yang ideal apabila sistem tersebut bisa mewujudkan goal congruence serta mampu mendorong para manajer untuk mencapai tujuan organisasi dengan cara-cara yang etis. Oleh karena itu, agar sistem penganggaran bisa efektif, maka kegiatan-kegiatan yang disusun harus mencerminkan upaya untuk mendukung tujuan suatu entitas.

Hal tersebut diperkuat dengan teori penetapan tujuan atau goal setting theory yang menjelaskan bahwa perilaku seseorang ditentukan oleh dua cognition yaitu content (values) dan intentions (tujuan) yang identik dengan perumusan anggaran. Orang telah menentukan goal (tujuan/ sasaran) atas perilakunya di masadepan dan goal tersebut akan mempengaruhi perilaku yang sesungguhnya terjadi yang akhirnya berdampak pada peningkatan kinerja entitas. Hal yang sama juga diungkapkan dalam teori atribusi yang menjelaskan bahwa bagaimana seorang penyelenggara anggaran berperilaku untuk mencapai kinerja manajerial. Sehinggaanggaran partisipatif berpengaruh terhadap kinerja manajerial dalam suatu entitas. Hal tersebut didukung oleh penelitian yang dilakukan oleh Karakoc (2016), Popesko (2017) dan Dahlan (2019) yang menyatakan bahwa partisipasi anggaran memiliki pengaruh yang signifikan secara statistik dan terhadap kinerja suatu entitas.

Berdasarkan uraian di atas, peneliti merasa perlu melakukan pengujian kembali mengenai pengaruh budget terhadap kinerja manajerial untuk memperkuat pendapatpendapat dari penelitian sebelumnya. Sehingga rumusan hipotesis yang diajukan adalah: $\mathrm{H}_{2}$ : Budget berpengaruh terhadap kinerja manajerial

\section{Pengaruh ketidakpastian lingkungan terhadap kinerja manajerial}

Ketidakpastian lingkungan pada teori kontinjensi dipelopori oleh Burn \& Stalker (1961) dalam Oktavianus (2002:15), yang mencoba mengidentifikasi tipe struktur dan praktik manajemen yang tepat untuk berbagai kondisi yang lingkungannya berbeda. Kedua peneliti tersebut menyimpulkan bahwa organisasi yang mekanis (dengan ciri pembagian tugas yang spesifik dan tegas) tepat untuk lingkungan yang stabil sedangkan 
organisasi yang organis (dengan ciri dan kontrollebih sulit dalam situasi operasi yang tidak pasti disebabkan oleh kejadian-kejadiandimasa akan datang tidak dapat diprediksi.

Hal tersebut diperkuat dengan teori kontinjensi yang menjelaskan bahwa kinerja organisasi bersifat contingen terhadap lingkungan yang dihadapi yang meliputi lingkungan perusahaan seperti; tingkat perubahan regulasi, tingkat perubahan ekonomi, tingkat perubahan teknologi informasi, tingkat perubahan pasar dan persaingan dan sebagainya. Burns dan Stalker (1961) yang mengembangkan contingency theory menyatakan bahwa lingkungan kerja yang stabil, kinerja organisasi atau entitasnya ditentukan oleh kemampuan manajemen berfokus kepada kegiatan rutin, hubungan lini yang kuat, serta penentuan tanggungjawab yang jelas. Sementara pada lingkungan organisasi yang dinamis, keberhasilan organisasi atau entitasnya ditentukan oleh fleksibilitas organisasi danskill karyawan yang dibutuhkan oleh perubahan lingkungan tersebut.

Mendukung teori tersebut, Rahmi (2019) melakukan penelitian tentang pengaruh ketidakpastian lingkungan terhadap kinerja manajerial. Dari hasil penelitiannya disimpulkan bahwa ketidakpastian lingkungan berpengaruh terhadapkinerja manajerial.. Penelitian tersebut juga didukung oleh Herawati (2015), Eriani (2019), Kesumawati (2019) dan Prihatningtyas (2018) yang menyatakan bahwa Ketidakpastian lingkungan berpengaruh positif dan signifikan terhadap kinerja manajerial, walaupun pada penelitian Bashirudin (2015) menyatakan bahwa ketidakpastian lingkungan tidak berpengaruh terhadap kinerja manajerial.

Berdasarkan uraian di atas, peneliti merasa perlu melakukan pengujian kembali mengenai pengaruh ketidakpastian lingkungan terhadap kinerja manajerial untuk memperkuat pendapat-pendapat dari penelitian sebelumnya. Sehingga rumusan hipotesis yang diajukan adalah:

$\mathrm{H}_{3}$ : Ketidakpastian lingkungan berpengaruh terhadap kinerja manajerial

\section{METODE PENELITIAN Jenis Penelitian}

Jenis penelitian yang digunakan dalam penelitian ini adalah penelitian asosiatif. Penelitian asosiatif adalah penelitian yang bertujuan untuk mengetahui hubungan antara dua variabel atau lebih. Pendekatan yang digunakan dalampenelitian ini adalah pendekatan kuantitatif yang bertujuan untuk menguji keandalan suatu teori yang kemudian akan menghasilkan kesimpulan-kesimpulan.

\section{Lokasi dan Waktu Penelitian}

Penelitian dilakukan pada koperasi syariah yang ada di Pulau Lombok yangterdiri atas 5 (lima) Kabupaten/Kota, yaitu Kota Mataram, Kabupaten Lombok Barat, Kabupaten Lombok Tengah, Kabupaten Lombok Timur dan Kabupaten Lombok utara. Pemilihan lokasi dilatarbelakangi oleh persebaran koperasi yang tidak merata di tiap Kabupaten/Kota serta untuk mendapatkan hasil penelitian yanglebih luas. Penelitian dilakukan pada Februari-April 2020.

\section{Teknik Pengumpulan Data}

Teknik pengumpulan data dalam penelitian ini adalah dengan cara menyebarkan kuesioner-kuesioner kepada responden yang dituju. Format pertanyaan dalam kuesioner bersifat tertutup, yaitu mengarahkan responden untuk menjawab atau berpendapat berdasarkan pilihan jawaban yang disediakan oleh peneliti dalam kuesioner.

\section{Populasi, Sampel dan Responden}

Populasi dalam penelitian ini adalah koperasi syariah di Pulau Lombok. Sampel 
dalam penelitian ini dipilih dengan menggunakan teknik penyampelan non-probabilitas dengan menggunakan metode penyampelan bertujuan (purposive sampling) yaitu pengambilan sampel berdasarkan kriteria-kriteria tertentu danpenilaian peneliti untuk mengarahkan sampel terpilih sesuai dengan tujuan penelitian. Adapun dalam penelitian ini sampel dipilih dari koperasi syariah yang masih aktif beroperasi. Responden dalam penelitian ini adalah 50 (lima puluh) manajer koperasi syariah di Pulau Lombok. Adapun daftar koperasi syariah dan rincian jumlah responden yang digunakan oleh peneliti dapat dilihat pada tabel.

\section{Jenis dan Sumber Data}

Jenis data yang digunakan dalam penelitian ini adalah data kuantitatif. Sumber data dalam penelitian ini adalah data primer. Data primer adalah data yangbelum pernah diolah oleh pihak tertentu untuk kepentingan tertentu. Data primer merupakan data yang diperoleh langsung melalui hasil kuesioner yang diberikan kepada responden. Dalam penelitian ini, pengukuran masing-masing indikator menggunakan skala likert. Menurut Sugiyono (2018:93), skala likert digunakan untuk mengukur sikap, pendapat, dan persepsi seseorang atau sekelompok orang tentang fenomena sosial. Dimana, dalam penelitian ini fenomena sosial tersebut ditetapkan sebagai variabel penelitian.

\section{Definisi Operasional Variabel}

\section{Sistem Informasi Akuntansi Manajemen $\left(\mathrm{X}_{1}\right)$}

Sistem informasi akuntansi manajemen adalah sistem informasi yang mengumpulkan data operasional dan finansial, memprosesnya, menyimpannya dan melaporkan kep ada pengguna, yaitu para pekerja, manajer dan eksekutif (Atkinson,dkk, 2012). Sistem akuntansi manajemen dapat menjadi mekanisme kontrol organisasi dan merupakan alat yang efektif dalam menyediakan informasi yang bermanfaat guna memprediksi konsekuensi yang mungkin dapat terjadi dari berbagai aktivitas yang bisa dilakukan (Nizarudin, 2006).

\section{Budget $\left(\mathrm{X}_{2}\right)$}

Anggaran atau budget merupakan suatu rencana yang disusun secara sistematis dalam bentuk angka dan dinyatakan dalam unit moneter yang meliputi seluruh kegiatan perusahaan untuk jangka waktu (periode) tertentu di masa yang akan datang. Agar sistem penganggaran bisa efektif, maka kegiatan-kegiatan yangdisusun harus mencerminkan upaya untuk mendukung tujuan entitas. Selain itu sistem penganggaran yang ada hendaknya bisa diwujudkan sesuai dengan ketentuan serta menghindari kemungkinan penyalahgunaan. Anggaran dapat diartikan sebagai perkiraan penerimaan dan pengeluaran yang diharapkan akan terjadi dalamsatu atau beberapa periode mendatang (Bastian: 2001, 79). Sehingga anggaran dapat mempengaruhi kinerja manajerial suatu entitas bisnis.

\section{Ketidakpastian Lingkungan (X3)}

Ketidakpastian lingkungan merupakan suatu kondisi lingkungan eksternal yang dapat memengaruhi operasionalisasi perusahaan (Otley, dalam Sulistiyowati, 2013). Ketidakpastian lingkungan yang tinggi akan menyebabkan manajer sulit menyusun perencanaan dan pengendalian organisasi yang tepat. Perencanaan yang disusun dalam situasi ketidakpastian lingkungan yang tinggi akan menjadi masalah karena adanya ketidakmampuan manajer untuk memprediksi kondisi pada masa mendatang (Dwirandra, 2007). Bagi perusahaan, sumber utama ketidakpastian yang berasal dari lingkungan luar, pesaing, pelanggan, pemasok, peraturan pemerintah, teknologi serta kondisi ekonomi dan politik (Sulistiyowati, 2013).

\section{Kinerja Manajerial (Y)}


Fitri dan Syam (2002), mendefinisikan kinerja sebagai suatu tindakanseseorang untuk memenuhi harapan yang berhubungan dengan fungsinya atau gambaran reaksi dari pekerjaannya. Rustiana (2002) memberikan definisi kinerja manajerial sebagai persespi kinerja individual para manajer yang terdiri dari delapan dimensi kegiatan yaitu perencanaan, investigasi, pengkoordinasian, supervisi, pengaturan staf, negoisasi, dan perwakilan. Juniarti dan Evelyne (2003) menyebutkan bahwa kinerja manajerial adalah ukuran seberapa efektif dan efisien manajer telah bekerja untuk mencapai tujuan organisasi.

\section{Instrumen Penelitian}

Instrumen dalam penelitian ini adalah kuesioner yang berisi pertanyaan untuk dijawab oleh responden. Instrumen tersebut disusun berdasarkan indikator yang terkandung dalam pengaruh sistem informasi akuntansi manajemen, budget dan ketidakpastian lingkungan terhadap kinerja manajerial yang kemudian dijabarkan dalam bentuk item-item yang memenuhi skala likert.

Pada tabel 3.1 dapat dilihat variabel dan masing-masing indikator yang digunakan dalam penelitian ini. Adapun secara rinci dapat dilihat pada tabel 3.1 berikut ini:

Tabel 3.1 Instrumen Penelitian

\begin{tabular}{|c|c|c|c|c|}
\hline Variabel & $\begin{array}{c}\text { Devinisi } \\
\text { Operasional }\end{array}$ & Indikator & $\begin{array}{c}\text { Skala } \\
\text { Pengukur } \\
\text { an }\end{array}$ & Kuesioner \\
\hline \multirow[t]{2}{*}{$\begin{array}{l}\text { Sistem Informasi } \\
\text { Akuntansi } \\
\text { Manajemen }\left(\mathrm{X}_{1}\right) \\
\text { (Hansen dan } \\
\text { Mowen }(2010)\end{array}$} & $\begin{array}{l}\text { Hansen dan Mowen } \\
(2015) \text { menjelaskan } \\
\text { sistem akuntansi } \\
\text { manajemen adalah } \\
\text { prosesyang }\end{array}$ & $\begin{array}{l}\text { Ruang lingkup } \\
\text { interval } \\
\text { (Broadscope) } \\
\text { Timeliness } \\
\text { (Ketepatanwaktu } \\
\text { informasi) }\end{array}$ & $\begin{array}{l}\text { Skala } \\
\text { Likert }\end{array}$ & $\begin{array}{l}1,2,3,4,5 \\
6,7,8\end{array}$ \\
\hline & $\begin{array}{l}\text { dideskripsikan oleh } \\
\text { aktivitas-aktivitas } \\
\text { sepertipengumpulan, } \\
\text { pengukuran, } \\
\text { penyimpanan, } \\
\text { analisis, pelaporan } \\
\text { danpengelolaan } \\
\text { informasi. }\end{array}$ & $\begin{array}{l}\text { Aggregation } \\
\text { (Dimensi } \\
\text { pengumpulan) } \\
\text { Integration }\end{array}$ & & $\begin{array}{l}9,10,11,12 \\
13,14,15, \\
16\end{array}$ \\
\hline $\begin{array}{l}\text { Budget }\left(\mathrm{X}_{2}\right) \\
\text { (Nainggolan, } \\
2019)\end{array}$ & $\begin{array}{l}\text { Partisipasi anggaran } \\
\text { merupakan interaksi } \\
\text { antaraatasan dan } \\
\text { bawahan dalam } \\
\text { menyusun rencana } \\
\text { kerjaserta tujuan } \\
\text { yangakan dicapai. } \\
\text { Proses penyusunan }\end{array}$ & $\begin{array}{l}\text { Keterlibatan } \\
\text { Pengaruh } \\
\text { Komitmen }\end{array}$ & $\begin{array}{l}\text { Skala } \\
\text { Likert }\end{array}$ & $\begin{array}{l}1,2,3,4,5 \\
6,7\end{array}$ \\
\hline
\end{tabular}




\begin{tabular}{|c|c|c|c|c|}
\hline Variabel & $\begin{array}{c}\text { Devinisi } \\
\text { Operasional }\end{array}$ & Indikator & $\begin{array}{c}\text { Skala } \\
\text { Pengukur } \\
\text { an }\end{array}$ & Kuesioner \\
\hline & $\begin{array}{l}\text { anggaran } \\
\text { memerlukan kerja } \\
\text { sama yang baik } \\
\text { antara atasan dan } \\
\text { bawahan } \\
\text { (Nainggolan, 2019) }\end{array}$ & & & \\
\hline $\begin{array}{l}\text { Ketidakpastian } \\
\text { Lingkungan }\left(\mathrm{X}_{3}\right) \\
\text { (Sulistiyowati, } \\
2013)\end{array}$ & $\begin{array}{l}\text { Ketidakpastian } \\
\text { lingkungan } \\
\text { merupakan suatu } \\
\text { kondisi lingkungan } \\
\text { eksternal yangdapat } \\
\text { memengaruhi } \\
\text { operasionalisasi } \\
\text { perusahaan (Otley, } \\
\text { dalamSulistiyowati, } \\
\text { 2013). }\end{array}$ & $\begin{array}{l}\text { Lingkunganluar } \\
\text { Informasi } \\
\text { perusahaanpesaing } \\
\text { Pelanggan } \\
\text { Pemasok } \\
\text { Peraturan } \\
\text { pemerintah } \\
\text { Teknologi } \\
\text { Informasi } \\
\text { Kondisi } \\
\text { ekonomi dan } \\
\text { politik }\end{array}$ & $\begin{array}{l}\text { Skala } \\
\text { Likert }\end{array}$ & $\begin{array}{l}1,2,3,4,5 \\
6,7,8,9, \\
10,11,12\end{array}$ \\
\hline $\begin{array}{l}\text { Kinerja } \\
\text { Manajerial (Y) }\end{array}$ & $\begin{array}{l}\text { Menurut Yazid } \\
(2012) \text { menyatakan } \\
\text { kinerja manajerial } \\
\text { adalah hasil kerja } \\
\text { yang dapat dicapai } \\
\text { oleh seseorang atau } \\
\text { kelompok orang } \\
\text { dalam suatu } \\
\text { organisasi, sesuai } \\
\text { dengan wewenang } \\
\text { dantanggung jawab } \\
\text { masingmasing dalam } \\
\text { rangkamencapai } \\
\text { tujuan } \\
\text { organisasi. }\end{array}$ & $\begin{array}{l}\text { Perencanaan } \\
\text { Investigasi } \\
\text { Koordinasi } \\
\text { Evaluasi } \\
\text { Pengawasan } \\
\text { PengaturanStaf } \\
\text { Negosiasi } \\
\text { Perwakilan(Narsa, } \\
\text { 2007) }\end{array}$ & $\begin{array}{l}\text { Skala } \\
\text { Likert }\end{array}$ & $\begin{array}{l}1,2,3,4,5, \\
6,7,8\end{array}$ \\
\hline
\end{tabular}

\section{Prosedur Analisis Data}

Dalam penelitian ini, untuk menguji hipotesis alat analisis yang digunakanadalah teknik Partial Least Square (PLS) dengan menggunakan aplikasi software SmartPLS 3.0. Partial Least Square (PLS) merupakan analisis persamaan Structural Equation Model (SEM) berbasis varian yang secara simultan dapat melakukan pengujian model pengukuran sekaligus pengujian model struktural. Model pengukuran digunakan untuk uji validitas dan reliabilitas, sedangkan modelstruktural digunakan untuk uji kausalitas atau pengujian hipotesis dengan model prediksi (Abdillah dan Jogiyanto, 2015:164). Terdapat tujuh langka yang harus dilalui dalam model PLS, antara lain: 
1. Merancang model struktural (inner model)

2. Merancang model pengukuran (outer model)

3. Merekonstruksi diagram jalur

4. Mengonversi diagram jalur ke sistem persamaan

5. Mengestimasi koefisien jalur dan nilai loading

6. Mengevaluasi goodness of fit

7. Melakukan pengujian hipotesis

HASIL PENELITIAN DAN PEMBAHASAN

Hasil Penelitian dan Gambaran Umum Responden

Tabel 4.1

Jumlah Kuesioner yang Disebar, Dikembalikan, dan Diolah

\begin{tabular}{|r|l|c|c|c|}
\hline No Nama KSP-PS/ BMT & $\begin{array}{c}\text { Kuesioner } \\
\text { disebar }\end{array}$ & $\begin{array}{c}\text { Kuesioner } \\
\text { yang } \\
\text { dikembalikan }\end{array}$ & $\begin{array}{c}\text { Kuesioner } \\
\text { yang diolah }\end{array}$ \\
\hline Mataram & & 1 & 1 \\
\hline 1 & $\begin{array}{l}\text { Koperasi syariah Angkasa Barokah RRI } \\
\text { Mataram }\end{array}$ & 1 & 1 & 1 \\
\hline 2 & Koperasi Syariah Sepakat Sejahtera & 2 & 2 & 2 \\
\hline 3 & KSU BMT Al-Iqtishady & 1 & 1 & 1 \\
\hline 4 & BMT Gumarang Akbar Syariah & 1 & 1 & 1 \\
\hline 5 & Koperasi Syariah Ammar Sasambo & 1 & 1 & 1 \\
\hline 6 & Koperasi Syariah Maju Bersama NTB & 1 & 1 & 1 \\
\hline 7 & Koperasi Syariah Sinar Lima Lombok & 1 & 1 & 1 \\
\hline 8 & Koperasi Syariah Bersama Sahabat & 1 & 1 & 1 \\
\hline 9 & Koperasi Syariah Bumi Gora Mandiri & 1 & 1 & 1 \\
\hline 10 & Koperasi Syariah 45 Mataram & & 0 & 0 \\
\hline 11 & Koperasi Syariah Hikmah Bersama Pagari & 1 & 1 & 1 \\
\hline & NTB & 1 & 1 & 1 \\
\hline Lombok Barat & 1 & 1 & 1 \\
\hline 12 & Kopsyah Mertasari Senggigi Lestari & 1 & 1 & 1 \\
\hline 13 & KSU Syariah Latalbi Nabi' Nubu' & 1 & 1 & 1 \\
\hline 14 & Koperasi Salimah NTB Sejahtera & 1 & 1 & 1 \\
\hline 15 & Koppontren Al-Mutaminnah & 1 & 1 & 1 \\
\hline 16 & KSU BMT Ta'awun & 1 & 1 & 1 \\
\hline 17 & Koperasi Pegawai Syariah Keluarga & 1 & 1 \\
\hline & SMKPP Negeri Mataram & Koppontren Sinar Lima & 1 & 1 \\
\hline 19 & Koppontren Nurul Hakim & 1 & 1 & 1 \\
\hline Lombok Tengah & Koperasi Tani Syariah Bina Usaha & 1 & 1 \\
\hline 20 & Koperasi Syariah Karya Muda Mandiri & 1 & 1 \\
\hline 22 & BMT Lumbung Bina Sejahtera & 1 & 1 \\
\hline 23 & KSPPS Sinar Amanah Sejahtera & 1 & 1 \\
\hline 24 & Koppontren Darul Aminin & 1 & 1 \\
\hline
\end{tabular}




\begin{tabular}{|c|c|c|c|}
\hline 25 KSPPS Bina Umat Sejahtera Jonggat & 1 & 1 & 1 \\
\hline \multicolumn{4}{|l|}{ Lombok Timur } \\
\hline $26 \begin{array}{l}\text { KSU Syariah BMT Al-Hidayah Ummat } \\
\text { Sejahtera-Pusat }\end{array}$ & 1 & 1 & 1 \\
\hline $27 \begin{array}{l}\text { KSU Syariah BMT Al-Hidayah Ummat } \\
\text { Sejahtera-Rarang }\end{array}$ & 1 & 1 & 1 \\
\hline $28 \begin{array}{l}\text { KSU Syariah BMT Al-Hidayah Ummat } \\
\text { Sejahtera-Sakra }\end{array}$ & 1 & 1 & 1 \\
\hline 29 KSU BMT Mandiri Syariah Pringgasela & 1 & 1 & 1 \\
\hline 30 KSU Syariah Anugerah Bersama & 1 & 1 & 1 \\
\hline \begin{tabular}{l|l}
31 & KSU Mandiri Syariah \\
\end{tabular} & 1 & 1 & 1 \\
\hline 32 BMT Tunas Harapan Syariah Pringgasela & 2 & 1 & 1 \\
\hline 33 KSPPS Barokah Lombok NTB & 1 & 1 & 1 \\
\hline $34 \begin{array}{l}\text { Koperasi Syariah Al-Ikhwan Amanah } \\
\text { Sejahtera }\end{array}$ & 1 & 1 & 1 \\
\hline \begin{tabular}{l|l}
35 & KSPPS BMT Lombok Bangkit \\
\end{tabular} & 1 & 1 & 1 \\
\hline 36 KSU BMT Permata Hidayatullah & 1 & 1 & 1 \\
\hline 37 KSU Syariah Ikhlas Mandiri & 1 & 1 & 1 \\
\hline 38 BMT Al-Hasan Rensing & 1 & 1 & 1 \\
\hline 39 KSPPS Itihadul Umah Al Madani & 1 & 1 & 1 \\
\hline \begin{tabular}{l|l}
40 & KSU Syariah Karya Terpadu \\
\end{tabular} & 1 & 0 & 0 \\
\hline \begin{tabular}{l|l}
41 & BMT Daaruzzakah \\
\end{tabular} & 1 & 0 & 0 \\
\hline 42 BMT Al-Hasan Rarang & 1 & 0 & 0 \\
\hline 43 BMT Al-Hasan Lenek & 1 & 0 & 0 \\
\hline 44 BMT Baituttamkin Lombok Timur & 1 & 0 & 0 \\
\hline \begin{tabular}{|l|l|}
45 & KSU BMT Al-Barokah Mandiri \\
\end{tabular} & 1 & 0 & 0 \\
\hline \multicolumn{4}{|l|}{ Lombok Utara } \\
\hline \begin{tabular}{|l|l|}
46 & Baituttamkin NTB unit Tanjung KLU \\
\end{tabular} & 1 & 1 & 1 \\
\hline 47 Kopsyah Manabiul Hikmah Jaya & 1 & 1 & 1 \\
\hline 48 BMT Al-Istiqomah & 1 & 1 & 1 \\
\hline Jumlah & 50 & 40 & 40 \\
\hline Persentase & & & $80 \%$ \\
\hline
\end{tabular}

Sumber: Data primer diolah 2020

\section{Analisis dan Hasil Penelitian}

\section{Uji Validitas}

\section{Validitas Konvergen (Convergent Validity)}

Uji validitas konvergen dalam PLS dengan indikator reflektif dinilai berdasarkan loading factor (korelasi antara skor item/skor komponen dengan skor konstruk) indikatorindikator yang mengukur konstruk tersebut. Semakin tinggi nilai factor loading, maka semakin penting peranan loading dalam menginterpretasimatrik faktor. Rule of thumb yang biasanya digunakan untuk mengukur validitas konvergen adalah outer loading $>$ 0,7, namun menurut Chin (1998) nilai loadin factor 0,5-0,6 masih dianggap cukup (Ghozali,2015:74). Nilai loading factor dalampenelitian ini ditunjukkan dalam tabel 4.2 sebagai berikut: 
Tabel 4.2 Loading Factor dengan Nilai Loading $>0,5$

\begin{tabular}{|c|c|c|c|c|c|}
\hline $\begin{array}{r}\text { No. } \\
\text { Item }\end{array}$ & $\begin{array}{c}\text { Sistem } \\
\text { Informasi } \\
\text { Akuntansi } \\
\text { Manajemen } \\
\text { (X1) }\end{array}$ & $\begin{array}{l}\text { Budgeting } \\
\text { (X2) }\end{array}$ & $\begin{array}{c}\text { Ketidakpastian } \\
\text { Lingkungan } \\
\text { (X3) }\end{array}$ & $\begin{array}{c}\text { Kinerja } \\
\text { Manajerial } \\
\text { (Y) }\end{array}$ & Keterangan \\
\hline $\mathrm{X} 1.1$ & 0.774 & & & & Valid \\
\hline $\mathrm{X} 1.2$ & 0.700 & & & & Valid \\
\hline $\mathrm{X} 1.3$ & 0.525 & & & & Valid \\
\hline X1.4 & 0.765 & & & & Valid \\
\hline $\mathrm{X} 1.7$ & 0.562 & & & & Valid \\
\hline $\mathrm{X} 1.12$ & 0.587 & & & & Valid \\
\hline $\mathrm{X} 1.13$ & 0.504 & & & & Valid \\
\hline $\mathrm{X} 1.14$ & 0.618 & & & & Valid \\
\hline $\mathrm{X} 1.15$ & 0.661 & & & & Valid \\
\hline $\mathrm{X} 1.16$ & 0.668 & & & & Valid \\
\hline $\mathrm{X} 2.1$ & & 0,667 & & & Valid \\
\hline $\mathrm{X} 2.2$ & & 0,658 & & & Valid \\
\hline $\mathrm{X} 2.3$ & & 0,896 & & & Valid \\
\hline $\mathrm{X} 2.4$ & & 0,677 & & & Valid \\
\hline $\mathrm{X} 2.5$ & & 0,579 & & & Valid \\
\hline $\mathrm{X} 2.6$ & & 0,556 & & & Valid \\
\hline X3.1 & & & 0,661 & & Valid \\
\hline X3.2 & & & 0,701 & & Valid \\
\hline X3.5 & & & 0,708 & & Valid \\
\hline X3.6 & & & 0,723 & & Valid \\
\hline X3.7 & & & 0,556 & & Valid \\
\hline X3.8 & & & 0,809 & & Valid \\
\hline $\begin{array}{l}X 3.9 \\
\end{array}$ & & & 0,714 & & Valid \\
\hline X3.11 & & & 0,785 & & Valid \\
\hline Y1.1 & & & & 0,500 & Valid \\
\hline Y1.2 & & & & 0,717 & Valid \\
\hline Y1.3 & & & & 0,623 & Valid \\
\hline Y1.4 & & & & 0,809 & Valid \\
\hline Y1.6 & & & & 0,716 & Valid \\
\hline Y1.7 & & & & 0,725 & Valid \\
\hline Y1.8 & & & & 0,603 & Valid \\
\hline
\end{tabular}

Sumber: data primer diolah 2020 
Tabel 4.3

Loading Factor dengan Nilai Loading $<0,5$

\begin{tabular}{|r|c|l|l|l|l|}
\hline NoItem & $\begin{array}{c}\text { Sistem } \\
\text { Informasi } \\
\text { Akuntansi } \\
\text { Manajemen } \\
\text { (X1) }\end{array}$ & lgeting(X2) & $\begin{array}{c}\text { Ketidakpastian } \\
\text { Lingkungan } \\
\text { (X3) }\end{array}$ & $\begin{array}{c}\text { Kinerja } \\
\text { Manajerial } \\
\text { (Y) }\end{array}$ & Keterangan \\
\hline X1.5 & 0,290 & & & & Tidak Valid \\
\hline X1.6 & 0,365 & & & & Tidak Valid \\
\hline X1.8 & 0,455 & & & & Tidak Valid \\
\hline X1.9 & 0,448 & & & & Tidak Valid \\
\hline X1.10 & 0,258 & & & & Tidak Valid \\
\hline X1.11 & 0,497 & & & & Tidak Valid \\
\hline X2.7 & & & 0,234 & & Tidak Valid \\
\hline X3.3 & & & 0,468 & & Tidak Valid \\
\hline X3.4 & & & $-0,071$ & & Tidak Valid \\
\hline X3.10 & & & 0,264 & & Tidak Valid \\
\hline X3.12 & & & & & Tidak Valid \\
\hline Y1.5 & & & & & \\
\hline
\end{tabular}

Sumber: data primer diolah 2020

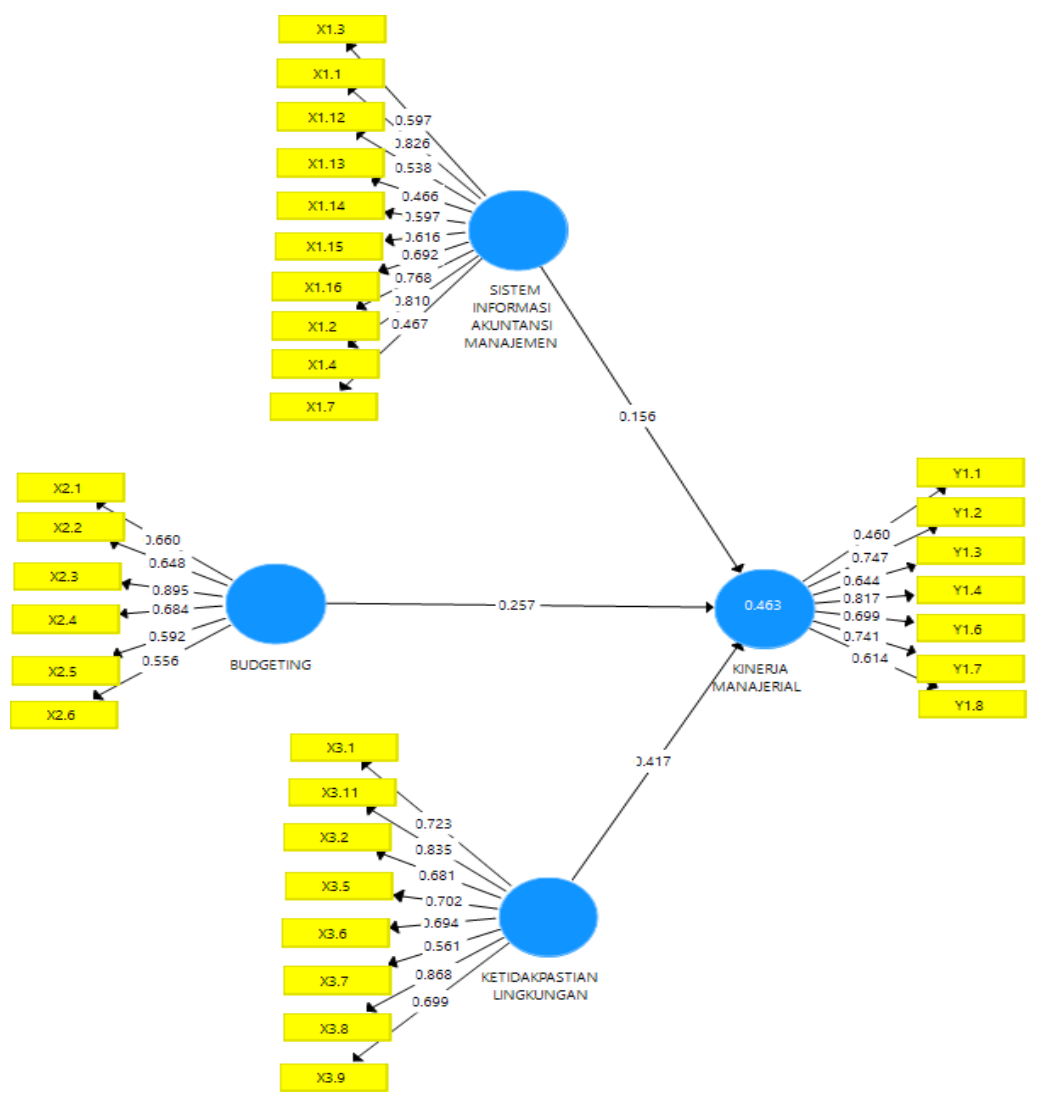

Gambar 4.8 Model Struktural 


\section{Validitas Diskriminan (Discriminant Validity)}

Validitas diskriminan terjadi jika dua instrumen yang berbeda, yang mengukur dua konstruk yang diprediksi tidak berkorelasi menghasilkan skor yang memang tidak berkorelasi (Hartanto, 2008:64 dalam Abdillah \& Jogiyanto, 2015:195). Untuk discriminant validity ini, setiap indikator diuji dengan cross loading. Dalam tabel 4.4 berikut, pengujian discriminant validity di gunakan untukmelihat bahwa masing-masing indikator di suatu konstruk akan berbeda dengan indikator dikonstruk lain dan mengumpul pada konstruk yang lainnya.

Tabel 4.4

\section{Cross Loading}

\begin{tabular}{|c|c|c|c|r|}
\hline No.Item & $\begin{array}{c}\text { Sistem } \\
\text { Informasi } \\
\text { Akuntansi } \\
\text { Manajemen } \\
\text { (X1) }\end{array}$ & $\begin{array}{c}\text { Budgeting } \\
\text { (X2) }\end{array}$ & $\begin{array}{c}\text { Ketidakpastian } \\
\text { Lingkungan } \\
\text { (X3) }\end{array}$ & $\begin{array}{c}\text { Kinerja } \\
\text { Manajerial } \\
\text { (Y) }\end{array}$ \\
\hline X1.1 & 0,826 & 0,227 & 0,441 & 0,462 \\
\hline X1.2 & 0,768 & 0,283 & 0,374 & 0,243 \\
\hline X1.3 & 0,597 & $-0,136$ & 0,030 & 0,155 \\
\hline X1.4 & 0,810 & 0,173 & 0,359 & 0,364 \\
\hline X1.7 & 0,467 & 0,219 & 0,213 & 0,124 \\
\hline X1.12 & 0,538 & 0,126 & 0,447 & 0,147 \\
\hline X1.13 & 0,466 & 0,243 & 0,190 & 0,077 \\
\hline X1.14 & 0,597 & 0,125 & 0,221 & 0,246 \\
\hline X1.15 & 0,616 & 0,291 & 0,240 & 0,199 \\
\hline X1.16 & 0,692 & 0,083 & 0,139 & 0,199 \\
\hline X2.1 & 0,168 & 0,660 & 0,279 & 0,287 \\
\hline X2.2 & 0,083 & 0,648 & 0,310 & 0,414 \\
\hline X2.3 & 0,173 & 0,895 & 0,444 & 0,422 \\
\hline X2.4 & 0,136 & 0,684 & 0,468 & 0,470 \\
\hline X2.5 & 0,367 & 0,592 & 0,408 & 0,257 \\
\hline X2.6 & 0,203 & 0,556 & 0,481 & 0,231 \\
\hline X3.1 & 0,278 & 0,244 & 0,723 & 0,370 \\
\hline X3.2 & 0,188 & 0,644 & 0,681 & 0,441 \\
\hline X3.5 & 0,135 & 0,333 & 0,702 & 0,398 \\
\hline X3.6 & 0,279 & 0,403 & 0,694 & 0,451 \\
\hline X3.7 & 0,451 & 0,368 & 0,561 & 0,506 \\
\hline X3.8 & 0,349 & 0,502 & 0,868 & 0,500 \\
\hline X3.9 & 0,327 & 0,495 & 0,699 & 0,501 \\
\hline X3.11 & 0,406 & 0,284 & 0,835 & 0,429 \\
\hline Y1.1 & $-0,120$ & 0,296 & 0,158 & 0,460 \\
\hline Y1.2 & 0,312 & 0,369 & 0,518 & 0,747 \\
\hline Y1.3 & 0,218 & 0,244 & 0,265 & 0,644 \\
\hline Y1.4 & 0,508 & 0,346 & 0,533 & 0,817 \\
\hline Y1.6 & 0,183 & 0,468 & 0,449 & 0,699 \\
\hline & & & & \\
\hline
\end{tabular}




\begin{tabular}{|c|c|c|c|c|}
\hline No.Item & $\begin{array}{c}\text { Sistem } \\
\text { Informasi } \\
\text { Akuntansi } \\
\text { Manajemen } \\
\text { (X1) }\end{array}$ & $\begin{array}{c}\text { Budgeting } \\
\text { (X2) }\end{array}$ & $\begin{array}{c}\text { Ketidakpastian } \\
\text { Lingkungan } \\
\text { (X3) }\end{array}$ & $\begin{array}{c}\text { Kinerja } \\
\text { Manajerial } \\
\text { (Y) }\end{array}$ \\
\hline Y1.7 & 0,162 & 0,522 & 0,526 & 0,741 \\
\hline Y1.8 & 0,418 & 0,277 & 0,383 & 0,614 \\
\hline
\end{tabular}

\section{Uji Reliabilitas}

Uji realibilitas dalam PLS menggunakan dua metode yaitu cronbach's alpha dan composite reliability. Cronbach's alpha mengukur batas bawah nilai reliabilitas suatu konstruk, sedangkan composite reliability mengukur nilai sesungguhnya reliabilitas suatu konstruk (Chin, 1995 dalam Abdillah \& Jogiyanto,2015:196). Untuk dapat dikatakan suatu konstruk yang reliable, maka nilai cronbach's alpha harus $>0,6$ dan nilai composite reliability harus $>0,7$. Berikut adalah hasil pengujian untuk cronbach's alpha dapat dilihat pada tabel 4.10 dan composite reliability dapat dilihat pada tabel 4.5.

\section{Tabel 4.5}

Cronbach's Alpha.

\begin{tabular}{|l|c|}
\hline \multicolumn{1}{|c|}{ Konstruk } & Cronbatch's Alpha \\
\hline Sistem Informasi Akuntansi Manajemen (X1) & 0.848 \\
\hline Budget (X2) & 0.765 \\
\hline Ketidakpastian Lingkungan (X3) & 0.868 \\
\hline Kinerja Manajerial (Y) & 0.807 \\
\hline
\end{tabular}

Sumber : data primer diolah 2020

Berdasarkan pada tabel 4.5 dapat diketahui nilai cronbach's alpha untuk sistem informasi akuntansi manajemen, budget, ketidakpastian lingkungan dan kinerja manejerial sudah berada di atas 0,6 yaitu sebesar 0,848 untuk variabel X1, 0,765 untuk variabel X2, 0,868 untuk variabel X3 dan 0,807 untuk variabel Y. Sehingga, dapat disimpulkan bahwa sistem informasi akuntansi manajemen, budget, ketidakpastian lingkungan dan kinerja manejerial sudah dianggap reliabel karena memiliki nilai cronbach's alpha di atas 0,6.

\section{Table 4.6}

Composite Reliability

\begin{tabular}{|l|c|}
\hline \multicolumn{1}{|c|}{ Konstruk } & Composite Reliability \\
\hline Sistem Informasi Akuntansi Manajemen (X1) & 0.876 \\
\hline Budget (X2) & 0.835 \\
\hline Ketidakpastian Lingkungan (X3) & 0.898 \\
\hline Kinerja Manajerial (Y) & 0.857 \\
\hline
\end{tabular}

Sumber : data primer diolah 2020

Berdasarkan tabel 4.6 dapat diketahui bahwa semua konstruk dapat dikatakan reliable karena setiap konstruk memiliki nilai diatas 0,7 . Sehingga dapatdikatakan bahwa konstruk pada penelitian ini memiliki realibilitas yang baik.

\section{Uji Hipotesis}

Uji hipotesis dilakukan untuk menjawab masalah penelitian yang telah dirumuskan sebelumnya dengan menggunakan software SmartPLS. Langkah selanjutnya 
setelah melakukan uji convergent validity dan discriminant validity, yaitu melakukan pengujian model structural (inner model). Nilai structural dapat dilihat melalui hasil estimasi koefisien parameter path dan tingkat signifikannya. Nilai $R$-square dapat dilihat pada tabel 4.7 dibawah ini:

Table 4.7

R-Square

\begin{tabular}{|l|c|}
\hline \multicolumn{1}{|c|}{ Konstruk } & R-Square \\
\hline Kinerja Manajerial (Y) & 0.463 \\
\hline
\end{tabular}

Sumber : data primer diolah 2019

Koefisien determinasi ( $R$-square) digunakan untuk menunjukkan seberapabesar pengaruh variabel yang mempengaruhi terhadap variabel yang dipengaruhi. Berdasarkan pada tabel 4.7 di atas menunjukkan bahwa $R$-square kontruk kinerja manajerial memiliki nilai sebesar 0,463. Hal ini berarti bahwa variabel sistem informasi akuntansi manajemen, budget, ketidakpastian lingkungan menjelaskan pengaruhnya terhadap kinerja manajerial sebesar $46,3 \%$, sedangkan sisanya yaitu sebesar 53,7\% dipengaruhi oleh variabel lain diluar dari penelitian ini Selanjutnya dilakukan $Q$-square test yang digunakan untuk mengevaluasi predictive relevance. Nilai $Q$-square lebih besar dari 0 (nol) menunjukkan bahwa model mempunyai predictive relevance, sedangkan nilai $Q$-square kurang dari 0 (nol) menunjukkan bahwa model kurang memiliki predictive relevance. Nilai $Q$-square didapatkandengan memasukkan nilai $R$-square kedalam rumus $Q$-square berikut:

$\mathrm{Q}^{2}=1-\left(1-\mathrm{R}^{2}\right)$

$=1-(1-0,463)$

$=0,463$

Berdasarkan hasil perhitungan yang dilakukan, diperoleh nilai $Q$-square yang sama dengan nilai $R$-square, sehingga dapat dijelaskan bahwa variabel laten yang digunakan dalam model memiliki relevansi prediksi. Selanjutnya pengujian hipotesis dilakukan dengan uji $t$ untuk menguji apakah variabel eksogen berpengaruh signifikansi terhadap variabel endogen. Dalam menguji hipotesis, dasar yang digunakan terdapat pada output result for inner weight berikut ini:

Table 4.8

Result For Inner Weight Path Coefficient (Mean, STDEV, T-Values)

\begin{tabular}{|l|c|c|c|c|c|c|c|}
\hline Keterangan & $\begin{array}{c}\text { Original } \\
\text { Sample } \\
(O)\end{array}$ & $\begin{array}{c}\text { Sample } \\
\text { Mean (M) }\end{array}$ & $\begin{array}{c}\text { Standar } \\
\text { Deviation } \\
\text { (STDEV) }\end{array}$ & $\begin{array}{c}\text { T-Statistics } \\
\text { (O/STDEV) }\end{array}$ & $\begin{array}{c}T \text { - } \\
\text { Table }\end{array}$ & Hipotesis & Keterangan \\
\hline $\begin{array}{l}\text { Sistem Informasi } \\
\text { Akuntansi } \\
\text { Manajemen (X1) } \\
-> \\
\text { Kinerja } \\
\text { Manajerial (Y) }\end{array}$ & 0.156 & 0.226 & 0.179 & 0.867 & 2,3 & 1 & Ditolak \\
\hline $\begin{array}{l}\text { Budget (X2) - } \\
\text { Kinerja } \\
\text { Manajerial (Y) }\end{array}$ & 0.257 & 0.258 & 0.151 & 1.696 & 2,3 & 2 & Ditolak \\
\hline
\end{tabular}




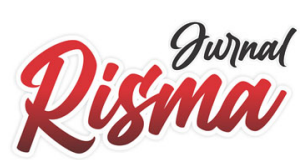

Vol. 1 No. 3 September 2021

\begin{tabular}{|l|c|c|c|c|c|c|c|}
\hline $\begin{array}{l}\text { Ketidakpastian } \\
\text { Lingkungan (X2) }\end{array}$ & 0.417 & 0.396 & 0.130 & 3.213 & 2,3 & 3 & Diterima \\
-> & & & & & & \\
\hline $\begin{array}{l}\text { Kinerja } \\
\text { Manajerial (Y) }\end{array}$ & & & & & & \\
\hline
\end{tabular}

Sumber: data primer diolah 2019

\section{Pembahasan}

\section{Pengaruh Sistem Informasi Akuntansi Manajemen terhadap Kinerja Manajerial}

Berdasarkan pada tabel 4.8 di atas, pengujian hipotesis pertama menunjukkan hubungan antara sistem informasi akuntansi manajemen dengankinerja manajerial adalah tidak signifikan karena nilai $t$-statistics $<2,3$ yaitu sebesar0,867. Sehingga dapat diketahui bahwa sistem informasi akuntansi manajemen tidak berpengaruh terhadap kinerja manajerial. Dengan demikian, dapat dikatakan bahwa hipotesis 1 (satu) yang menyatakan bahwa sistem informasi manajemen berpengaruh terhadap kinerja manajerial ditolak.

Hasil penelitian tersebut diperkuat dengan data keikutsertaan koperasi syariah dalam pelatihan sistem informasi akuntansi yang lebih dari 3 (tiga) kali hanya $30 \%$ sedangkan yang mengikuti pelatihan sistem informasi akuntansi manajemen kurang dari 3 (tiga) kali sebanyak 38\% dan tidak pernah mengikuti sebanyak 33\%. Selain itu, hasil penyebaran kuesioner menunjukkan bahwa 11\% responden kurang setuju bahwa dengan sistem informasi akuntansi manajemen mempengaruhi kinerja manajerial, 28\% responden masih mendapatkan informasi yang terbatas mengenai pengaruh keputusan yang diambil di dalam koperasi syariah dan hanya $20 \%$ responden yang benar-benar mendapatkan informasi laporan keuangan baik secara bulanan atau kuartalan.

Pada koperasi syariah yang diteliti belum banyak yang melakukan pembagian tugas dan wewenang secara jelas melalui pembagian departemen, sehingga semua hal mengenai koperasi terpusat hanya kepada manajer. Hal ini jugadikarenakan koperasi syariah di Pulau Lombok masih dikategorikan sebagai entitasusaha berskala kecil dan core bisnisnya tidak terlalu luas sehingga masih menggunakan sistem informasi secara manual dan belum terkomputerisasi. Selain itu, ruang lingkup sistem informasi akuntansi manajemen seperti broadscope, timeliness, aggregation dan integration masih terbatas dan belum sepenuhnya diterapkan oleh koperasi syariah.

Pada sektor mikro seperti koperasi syariah keinginan untuk berubah memang relatif kecil dibandingkan dengan perusahaan manufaktur. Selain itu jika dilihat dari usia responden didominasi oleh usia lebih dari 40 tahun dan 50 tahun sehingga pengetahuan mengenai sistem informasi masih kurang dan terbatas kepada pengetahuan mengenai koperasi syariah.

Hasil penelitian mendukung implikasi teori perilaku terencana (planned behavior theory). Yaitu sikap seorang manajer dalam menggunakan sistem informasi untuk meningkatkan kinerja manajerial yang tidak terlepas pada attitudetoward behavior, subjective norm dan perceived behavior control. Planned behavior theory yang mempengaruhi sikapnya dalam pengambilan keputusan sesuai dengan keadaan dan kebutuhan entitasnya. Jika sistem informasi akuntansi manajemen tidak dirasa perlu maka, manajer tidak mengimplementasikannya.Selain itu penelitian ini berkaitan dengan teori kontijensi yang menyatakan bahwa perilaku manajer tergantung kepada lingkungan bisnis, semakin baik dan lingkungan bisnis dan keinginan berkembangnya tinggi maka kinerja manajer akanmeningkat sejalan dengan meningkatnya penerapan sistem informasi dan pengendalian internal yang lebih baik.

Hasil penelitian ini berkebalikan dengan penelitian yang dilakukan oleh Bashirudin (2015), Herawati (2015), Angelina (2018), Irawati (2018), 
Prihatningtyas (2018), Suryani (2019), Dahlan (2019) dan Rahmi (2019) yang menyatakan bahwa sistem informasi akuntansi berpengaruh terhadap kinerja manajerial. Namun aspek penelitian yang dilakukan pada skala usaha yang besar sehingga hasil penelitian berpengaruh signifikan. Walaupun demikian hasil penelitian sejalan dengan penelitian Yunifa Fujiastuti (2008) yang menunjukkan bahwa sistem informasi akuntansi manajemen tidak berpengaruh terhadap kinerja manajerial.

\section{Pengaruh Budget terhadap Kinerja Manajerial}

Berdasarkan pada tabel 4.8 di atas, pengujian hipotesis kedua menunjukkanantara budget dan kinerja manajerial tidak memiliki pengaruh. Hal ini dapat dilihatnilai $t$ statistics $<2,3$ yaitu 1,696 yang berarti tidak memiliki keterkaitan atau pengaruh antara keduanya. Dengan demikian, dapat dikatakan bahwa hipotesis 2 (dua) yang menyatakan bahwa budget berpengaruh signifikan terhadap kinerja manajerial ditolak.

Hasil penelitian juga diperkuat dengan hasil dari penyebaran kuesioner mengenai budget, yang dapat dilihat dari indikator-indikator yang digunakan dalampenelitian ini. Hasil penyebaran kuesioner menyatakan bahwa $22 \%$ responden tidaksetuju bahwa budget mempengaruhi kinerja manajerial, 59\% koperasi syariah mengalami kendala dalam penyusunan anggaran partisipatif serta $15 \%$ responden tidak yakin bahwa anggaran partisipatif akan mampu memberikan dampak yang besar untuk kemajuan koperasi syariah. Selain itu 15\% responden tidak memiliki kontribusi yang besar dalam penyusunan anggaran dan sebanyak $28 \%$ tidak memiliki pengaruh yang besar pada anggaran akhir koperasi syariah.

Hasil penelitian mendukung implikasi teori terencana atau goal-setting yaitu suatu entitas dalam menjalankan perannya untuk turut mengikutsertakan bagian-bagian entitas untuk berpartisipasi dalam perumusan anggaran. Namun padaentitas dengan core bisnis yang kecil sasaran (goal) biasanya tidak dibuat secara spesifik dan tersusun melalui penyusunan anggaran sehingga tidak berpengaruh pada kinerja entitas tersebut. Penelitian ini juga mendukung teori atribusi yang menjelaskan bagaimana seorang penyelenggara anggaran berperilaku. Kemampuanpenyelenggara anggaran dalam mencapai tujuan dan kinerja organisasi banyak ditentukan oleh atribusi internal, yaitu dari dalam diri penyelenggara anggaran sehingga apabila penyelenggara anggaran tidak melakukan proses anggaran denganbaik dan benar maka hal tersebut tidak akan berpengaruh dengan kinerja manajerial. Hal tersebut dikarenakan proses anggaran sudah dianggap biasa sehingga tidak rutin dilakukan setiap tahunnya.

Hasil penelitian ini sejalan dengan penelitian terdahulu yang dilakukan Fitra(2009) dan Hafridebri (2013) yang menyatakan bahwa partisipasi anggaran tidak berpengaruh terhadap kinerja manajerial. Walaupun hasil penelitian berkebalikan dengan penelitian Karakoc (2016) dan Dahlan (2019) yang menyatakan bahwa partisipasi anggaran memiliki pengaruh yang signifikan terhadap kinerja suatu entitas.

\section{Pengaruh Ketidakpastian Lingkungan terhadap Kinerja Manajerial}

Berdasarkan pada tabel 4.8 di atas, pengujian hipotesis ketiga juga menunjukkan adanya pengaruh positif antara budget dan kinerja manajerial. Hal ini dapat dilihat melalui nilai $t$-statistics $>2,3$ yaitu sebesar 3,213 yang berarti memiliki keterkaitan antara keduanya. Dengan demikian, dapat dikatakan bahwa hipotesis 3(tiga) yang menyatakan bahwa ketidakpastian lingkungan berpengaruh signifikan terhadap kinerja manajerial dapat diterima.

Hasil penelitian ini juga diperkuat dengan hasil dari penyebaran kuesioner mengenai budget, yang dapat dilihat dari indikator-indikator yang digunakan dalam penelitian ini. Hasil penyebaran kuesioner menyatakan bahwa sebanyak $31 \%$ responden 


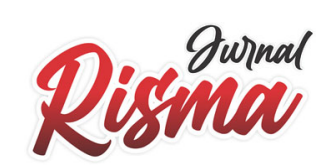

Vol. 1 No. 3 September 2021

memberikan tanggapan bahwa sulit untuk menentukan metode untuk mampu mencapai sasaran koperasi, 58\% responden sering menghadapi masalah baru atau tidak biasa berkenaan dengan anggaran, 53\% responden ketika mengerjakan pekerjaan manajer sulit untuk mengukur apakah manajer membuat keputusan yang benar, dan $60 \%$ menjawab bahwa unsur-unsur di luar pengendaliannya mempengaruhi keputusan-keputusan yang dibuat dalam koperasisehingga ketidakpastian berpengaruh pada kinerja koperasi syariah.

Adapun hasil penelitian ini juga mendukung implikasi teori kontinjensiyang menjelaskan bahwa kinerja organisasi bersifat contingen terhadap lingkungan yang dihadapi yang meliputi lingkungan perusahaan seperti; tingkat perubahanregulasi, tingkat perubahan ekonomi, tingkat perubahan teknologi informasi,tingkat perubahan pasar dan persaingan dan sebagainya. Burns dan Stalker (1961)yang mengembangkan contingency theory menyatakan bahwa lingkungan kerjayang stabil, kinerja organisasi atau entitasnya ditentukan oleh kemampuanmanajemen berfokus kepada kegiatan rutin, hubungan lini yang kuat, sertapenentuan tanggungjawab yang jelas. Sementara pada lingkungan organisasi yangdinamis, keberhasilan organisasi atau entitasnya ditentukan oleh fleksibilitas organisasi dan skill karyawan yang dibutuhkan oleh perubahan lingkungan tersebut.Chandler (1962) dan Donaldson (2001) menyatakan bahwa intisari contingency theory terletak pada konsep " $f i t$ " atau kesesuaian. Konsep fit berasumsibahwa keberhasilan kinerja organisasi bergantung pada tingkat kesesuaian antarakarakteristik internal organisasi dengan contingent factors dimana organisasi tersebut beroperasi. Perubahan contingent factor mengakibatkan ketidaksesuianantara oragniasi dan contingent factors sehingga berpotensi menurunkan kinerja manajerial organisasi. Oleh karena itu, organisasi syaratkan untuk kembali menyesuaikan dengan lingkungan yang baru. Pemilihan strategi untuk penyelarasan kembali tersebut bersifat situasional. Menurut Bourgeois dan Brodwin (1984), strategi organisasi yang mampu menyesuaikan kembali dengan lingkungan barunya dapat memperbaiki kinerja organisasi tersebut.

Mendukung teori tersebut, Rahmi (2019) melakukan penelitian tentang pengaruh ketidakpastian lingkungan terhadap kinerja manajerial. Dari hasil penelitiannya disimpulkan bahwa ketidakpastian lingkungan berpengaruh terhadapkinerja manajerial. Ketidakpastian lingkungan yang tinggi diidentifikasi sebagai faktor yang penting karena kondisi demikian dapat menyulitkan perencanaan dan pengendalian. Penelitian tersebut juga didukung oleh Herawati (2015), Eriani (2019), Kesumawati (2019) dan Prihatningtyas (2018) yang menyatakan bahwa Ketidakpastian lingkungan berpengaruh positif dan signifikan terhadap kinerja manajerial.

\section{PENUTUP}

\section{Simpulan}

Penelitian ini bertujuan untuk mengetahui pengaruh sistem informasiakuntansi manajemen, budget dan ketidakpastian lingkungan terhadap kinerjamanajerial koperasi syariah. Berdasarkan pemaparan yang telah dijelaskan pada bab sebelumnya, maka dapat disimpulkan:

1. Sistem informasi akuntansi manajemen tidak berpengaruh terhadap kinerja manajerial. Hal ini menunjukkan bahwa broadscope (informasi yang memiliki cakupan yang luas dan lengkap), agregastion (Informasidisampaikan dalam bentuk yang lebih ringkas), integration (Informasi yangterintegrasi) dan timeliness btidak berpengaruh terhadap kinerja manajerial koperasi syariah. Sehingga dapat disimpulkan bahwa penerapan sistem informasi akuntansi manajemen yang tinggi 
atau rendah tidak berpengaruhsecara signifikan terhadap kinerja manajerial.

2. Budget tidak berpengaruh terhadap kinerja manajerial. Hal ini menunjukkan bahwa dengan adanya partisipasi anggaran yang tinggi dalam koperas syariah tidak mampu mewujudkan kinerja manajerial koperasi syariah yang lebih baik. Sehingga dapat disimpulkan bahwa semakin tinggi atau rendah tingkat partisipasi anggaran tidak berpengaruh pada kinerja manajerial koperasi syariah.

3. Ketidakpastian lingkungan berpengaruh terhadap kinerja manajerial. Hal ini menunjukkan bahwa walaupun koperasi syariah berskala kecil dan core bisnisnya tidak terlalu luas perubahan-perubahan lingkungan usaha sering terjadi. Hal tersebut mengakibatkan kemampuan manajer dalam memprediksi kemungkinankemungkinan yang akan terjadi dan mengidentifikasi tipe struktur dan praktik manajemen yang tepat untuk berbagai kondisi yang lingkungannya berbeda mempengaruhi kinerja manajerial koperasi syariah.

\section{Implikasi Penelitian}

Hasil dari temuan penelitian ini mempunyai implikasi bagi koperasisyariah, baik manajer koperasi syariah, pengawas maupun anggota koperasi syariah secara umum khususnya di Pulau Lombok dalam mengambil keputusan dalam merumuskan kebijakan terkait penerapan sistem informasi akuntansi manajemen,budget dan mampu mengantisipasi ketidakpastian lingkungan serta dapat membuatkeputusan-keputusan yang tepat untuk meningkatkan kinerja manajerial.Penelitian ini juga mempunyai implikasi bagi peneliti selanjutnya, diharapkan dapat menjadikan penelitian ini sebagai referensi atau literatur dalammenelaah beragam permasalahan terutama yang berkaitan dengan koperasi syariah. Dengan memiliki pemahaman yang mendalam mengenai pengaruh sisteminformasi akuntansi manajemen, budget dan ketidakpastian lingkungan diharapkan dapat memberikan kontribusi pada pengembangan literatur dan implikasi bagi para praktisi dan akademisi.

\section{Keterbatasan dan Saran Penelitian}

Dalam penelitian ini, terdapat beberapa keterbatasan yang dapat dijadikanacuan sebagai keterbaruan bagi peneliti selanjutnya yang akan mengangkat tema yang sama, diantaranya:

1. Pengambilan lokasi dalam penelitian ini hanya terfokus pada koperasi syariah di Pulau Lombok. Diharapkan bagi peneliti selanjutnya untuk memperluas lokasi penelitian dengan mengambil lebih banyak sampel, misalnya koperasi syariah di NTB atau beberapa provisi di Indonesiasehingga dapat memperkuat hasil penelitian.

2. Variabel dalam penelitian ini terbatas kepada sistem informasi akuntansi manajemen, budget dan ketidakpastian lingkungan sehingga penelitian ini perlu dikembangkan agar lebih mendalam, salah satunya dengan menambahvariabel-variabel lainnya yang mempengaruhi kinerja menajerial seperti implementasi teknologi informasi, pengendalian internal, budaya manajemen syariah, dan lainnya sehingga akan mendapatkan hasil empiris yang lebih akurat.

3. Teknik pengumpulan data dalam penelitian ini dilakukan dengan penyebaran kuesioner, sehingga diperoleh hasil penelitian yang rentanterhadap biasnya jawaban responden. Tidak hanya itu, adanya kumungkinan bahwa jawaban yang diberikan tidak sesuai dengan keadaan yang sesungguhnya disebabkan secara umum responden akan memberikan jawaban yang baik atas pertanyaan yang diajukan terutama terkait dengan kinerja masing-masing. Oleh karena itu, disarankan bagi penelitian selanjutnya tidak hanya menggunakan kuesioner saja melainkan juga dapat menggunakan wawancara dan observasi sehingga akan mendapatkan hasil penelitian 


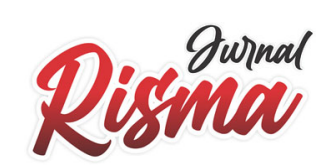

Vol. 1 No. 3 September 2021

yang lebih valid.

\section{DAFTAR PUSTAKA}

Abdillah, Willy; Jogiyanto. (2015). Partial Least Square (PLS) Alternatif Structural Equation Modeling (SEM) dalam Penelitian Bisnis. Yogyakarta,Indonesia: ANDI

Adnan. 2012. Business Plan Project Pendirian Koperasi Jasa Keuangan Syariah Mitra Maju Sejahtera: Rencana Operasional dan Sumber Daya Manusia.

Angelina, Nita. 2018. Pengaruh ketidakpastian lingkungan terhadap kinerja manajerial dengan sistem akuntansi manajemen sebagai variabel moderasi pada perusahaan manufaktur di Surabaya. Undergraduate thesis, Widya Mandala Catholic University Surabaya.

Anita, Hunaini. 2020. Pengaruh Akuntabilitas Dan Kompetensi Sumber Daya Manusia Dalam Pengelolaan Keuangan Desa Terhadap Pembangunan Desa. Universitas Mataram

Atkinson, Anthony A, Kaplan, Robert S. Ella Mae Matsumura, Young, S Mark (2012), Akuntansi Manajemen, Edisi kelima, Jilid 2, Penerbit PT. Indeks, Jakarta.

Bashirudin, Achmad. 2015. Pengaruh Sistem Informasi Akuntansi Manajemen, Human Capital Dan Ketidakpastian Lingkungan Terhadap Kinerja Manajerial Pada Baitul Maal wat Tamwil Di Wilayah DKI Jakarta. Skripsi 2015.

Chenhall, Robert H. dan Deigan, Morris. 1986. The Impact of Structure, Environment, and Interdependence on the Perceived Usefulness of Management Accounting Systems. The Accounting Review, No.1, pp.16-35.

Chin. 1995. Decentralization, Management Accounting System (MAS) Informantion Characteristic, and Their Interaction Effects on Managerial Performance, A Singapore Study. Journal of Bussiness Financial Accounting

Chong, Vincent K, dan Chong, Karming (1997). Strategic Choices, Enviromnental Uncertainty and SBU Performance: A Note on the Intervening Role of Management Accounting Systems.

Dahlan, Muhammad. 2018. The Effect of Management Accounting Systems and Interactive Budget Use on Job Performance. Asia Proceedings of Social Sciences Vol 3 No 1; 50-53

Dahlan, Muhammad. 2019. Analysis of interrelationship between usefulness of management accounting systems, interactive budget use and job performance. Management Science Letters 9 (2019) 967-972

Dinas Koperasi dan UMKM Provinsi NTB. 2019. Daftar Nama dan Rekapitulasi Koperasi Syariah di Nusa Tenggara Barat. Oktober 2019

Draft, Richard. L. "Manajemen”. Salemba Empat, Jakarta, 2007

Endang Raino Wirjono. 2013. Hubungan Antara Sistem Akuntansi Manajemen Dan Ketidakpastian Lingkungan Yang Dirasakan Terhadap Kinerja Manajerial. Jurnal Ilmiah Akuntansi dan Bisnis, Vol. 8 No. 1 Januari

Eriani, Izmi Dwira. 2019. Ketidakpastian Lingkungan dan Kinerja Manajerial: Peran Mediasi Sistem Akuntansi Manajemen. Jurnal Reviu Akuntansi dan Keuangan, vol 9 no 3, p. 255-268

Fidiana, 2017. Tinjauan Kritis Kesyariahan Koperasi Syariah. Jurnal Ekonomi dan Perbankan Syariah Vol. 4. No.2 Desember 2017

Ghozali, Imam. 2011. Aplikasi Analisis Multivariate dengan Program SPSS. Semarang: Badan Penerbit UNDIP

Gordon, L. A. dan D. Miller. (1986). A Contingency Framework for the Design of 
Accounting Information Systems. Accounting Organizations and Society, Vol. 1 No. 1, pp. 59-69.

Hansen, Don R dan Mowen, Maryanne M. 2010. Akuntansi Manajemen. Jakarta: Erlangga.

Harmoyo. 2011. Analisis Manajemen Strategi Koperasi Jasa Keuangan Syariah Baitul Maal Wat Tamwil "Syariah Sejahtera" Boyolali.

Herawati, Tuti. 2015. Pengaruh Ketidakpastian Lingkungan Dan Karakteristik Informasi Sistem Akuntansi Manajemen Terhadap Kinerja Manajerial. STAR - Study \& Accounting Research Vol XII, No.1 - 2015

Irawati, Anik. 2018. Pengaruh Karakteristik Sistem Informasi Akuntansi Manajemen Terhadap Kinerja Manajerial Dengan Desentralisasi Sebagai Variabel Moderating. JURNAL Akuntansi \& Keuangan Vol. 9, No. 1, Maret 2018 Halaman $34-53$

Karakoc, Emine Yilmaz. 2016. The Budget Related Antecedents of Job Performance. International Journal of Research in Business \& Social Science Vol 5 No 3

Kesumawati, Ni Ketut Ayuk. 2019. The Role of Business Strategies, Environmental Uncertainty and Decentralization as Moderating the Effect of Management Accounting Systems on Managerial Performance. International Research Journal of Management, IT \& Social Sciences Vol. 6 No. 3, pages: 37-45

Kristianto, Yanssen. 2018. Keterpengaruhi Kinerja Manajerial Oleh Ketidakpastian Lingkungan Dan Desentralisasi; Studi Pada Usaha Ritel Lawson, Jakarta. Journal of Business \& Applied Management Vol.11 (No. 2): 204 - 238.

Kusmaningtia, Wulan. 2014. Praktik Risk Management Pembiayaan Mikro.Bandung: Universitas Pendidikan Indonesia

Lasmiatun. 2010. Perbankan Syari'ah. LPSDM. Semarang: RA Kartini

Mahoney, T. A., T. H. Jerdee and S. J. Carroll. 1963. Development of Managerial Performance: A Research Approach. Cincinnati: South Western Publ. Co.

Otley, D. T., (1980), The Contingency Theory of Management Accounting aehievemen and Prognosis. Accounting Organizations and Society. Vol. 5 No. 4, pp. 413-428.

Popesko, Boris. 2017. The Maturity of a Budgeting System and its Influence on Corporate Performance. Acta Polytechnica Hungarica Vol. 14, No. 7.

Rahmi. 2019. Pengaruh Sistem Informasi Akuntansi Manajemen, Ketidakpastian Lingkungan, Human Capital Terhadap Kinerja Manajerial Pada PT Bosowa Berlian Motor Makassar. Bongaya Journal for Research in Accounting Vol.2 No. 2 Oktober 2019

Sholihin, A.I., Buku Pintar Ekonomi Syariah. 2010: PT Gramedia Pustaka Utama. Sugiyono, 2014. Metode Penelitian Kuantitatif Kualitatif dan R\&D. Bandung: Alfabeta

Suparmun, Haryono. 2015. Pengaruh partisipasi anggaran terhadap kinerja manajerial: Komitmen organisasi dan ketidakpastian lingkungan sebagai moderasi. Jurnal bisnis dan akuntansi Vol. 17, No 1, Juni 2015, Hal 77-84.

Suryani. 2019. Pengaruh Karakteristik Informasi Sistem Akuntansi Manajemen Terhadap Kinerja Manajerial Dengan Ketidakpastian Lingkungan Dan Desentralisasi Sebagai Variabel Moderating. Jurnal Akuntansi dan Keuangan - Vol. 8, N0. 1.

Walfajri, Maizal. 2017. 324 Koperasi Syariah Jateng Terancam Tutup. https://amp.kontan.co.id. Dikses pada 23 Januari 2020 Pukul 09.00 WITA

Wiroso. 2005. Jual Beli Murabahah. Yogyakarta: UII Press 